\title{
Pengungkapan Corporate Social Responsibility (CSR) sesuai dengan Prinsip Ekonomi Syariah
}

\author{
Muhammad Fiqri \\ Institut Agama Islam Negeri (IAIN) Bone \\ muhfiqri1996@yahoo.com
}

\author{
Yaman \\ Sekolah Tinggi Agama Islam (STAI) Al-Furqan Makassar \\ yaman77@gmail.com
}

\begin{abstract}
This study discusses a review of Islamic economic principles towards disclosure of corporate social responsibility (CSR). This study aims to determine whether CSR disclosure indicators in the annual report of PT. Semen Tonasa, Tbk in accordance with sharia economic principles. Research Results Shows disclosure of social responsibility includes economic aspects, social aspects, environmental aspects, aspects of labor, aspects of human rights, and product aspects that occur in the company. Social responsibility in CSR practices for disclosure of CSR activities to the community is very important. This is in accordance with the fundamental principles that shape the philosophy of environmental virtues carried out holistically by the Prophet Muhammad SAW, namely the belief in the interdependence between God's creatures. Islam requires circulation of wealth to occur to all members of society and prevents the circulation of wealth to only a few people. Allah SWT said: "... so that the treasure should not be circulated among the rich only among you." (QS. Al-Hasyr: 7)
\end{abstract}

Keywords: Disclosure of CSR, Principles of Sharia Economics.

\begin{abstract}
Abstrak
Penelitian ini membahas tentang tinjauan prinsip ekonomi syariah terhadap pengungkapan corporate social responsibility (CSR). Penelitian ini bertujuan untuk mengetahui apakah indikator-indikator pengungkapan CSR pada laporan tahunan PT. Semen Tonasa, Tbk sesuai dengan prinsip ekonomi syariah. Hasil Penelitian Menunjukkan Pengungkapan tanggung jawab sosial meliputi aspek ekonomi, aspek sosial, aspek lingkungan, aspek tenaga kerja, aspek hak asasi manusia, dan aspek produk yang terjadi di perusahaan. Tanggung jawab sosail dalam praktik CSR untuk pengungkapan aktivitas-aktivitas CSR kepada masyarakat penting sekali dilakukan. Hal ini sesuai dengan prinsip-prinsip mendasar yang membentuk filosofi kebajikan lingkungan yang dilakukan secara holistik oleh Nabi Muhamad SAW yaitu keyakinan akan adanya saling ketergantungan di antara makhluk ciptaan Allah. Islam mewajibkan sirkulasi kekayaan terjadi pada semua anggota masyarakat dan mencegah terjadinya sirkulasi kekayaan hanya pada segelintir orang. Allah SWT berfirman: "...supaya harta itu jangan beredar di antara orang-orang kaya saja di antara kamu." (QS. Al-Hasyr: 7)
\end{abstract}

Kata Kunci: Pengungkapan CSR, Prinsip Ekonomi Syariah. 


\section{PENDAHULUAN}

Dunia bisnis saat ini dihadapkan pada dua hal yang bertentangan. Di satu sisi, para pelaku bisnis harus berupaya untuk dapat memperoleh laba yang tinggi dan untuk mendukung hal tersebut perlu disertai dengan adanya penekanan biaya. Di sisi lain, perusahaan harus bertanggung jawab terhadap lingkungan secara khusus tempatnya beroperasi. Saat ini, masyarakat semakin berani untuk mengekspresikan berbagai tuntutannya kepada pemerintah. Tidak hanya pada pemerintah, tuntutan masyarakat terhadap perusahaan kini juga semakin besar. ${ }^{1}$ Corporate social responsibility (CSR) merupakan klaim stakeholders agar perusahaan tidak hanya beroperasi untuk kepentingan para pemegang saham (shareholders), tapi juga untuk kemaslahatan pihak stakeholders dalam praktik bisnis, yaitu para pekerja, komunitas lokal, pemerintah, Lembaga Swadaya Masyarakat (LSM), konsumen, dan lingkungan. Oleh karena itu, sebuah perusahaan bertanggung jawab kepada banyak stakeholders, yaitu para pemegang saham, konsumen, para pegawai, para pemasok, dan masyarakat. ${ }^{2}$

Tanggung jawab sosial semakin menjadi perhatian bagi dunia bisnis, hal ini berkaitan dengan adanya kesadaran suatu perusahaan atau institusi untuk tidak hanya menghasilkan laba setinggi-tingginya, tetapi juga bagaimana laba tersebut dapat memberikan manfaat kepada masyarakat. Konsep Corporate Social Responsibility mengarah kepada transparansi yang diungkapkan tidak hanya informasi keuangan perusahaan saja, tetapi juga diharapkan mengungkapkan informasi mengenai dampak sosial serta lingkungan hidup yan r Niakibatkan oleh aktivitas. ${ }^{3}$

Apabila perusahaan tidak 1 ...u. iperhatikan seluruh faktor yang mengelilinginya, mulai dari karyawan, konsumen, lingkungan dan sumber daya alam sebagai satu kesatuan yang saling mendukung suatu sistem, maka tindakan itu akan mengakhiri eksistensi perusahaan itu sendiri. Kerusakan dan gangguan yang timbul dari faktor

\footnotetext{
${ }^{1}$ Anggara Satria Putra, "Pengaruh Corporate Social Responsibility terhadap Profitabilitas Perusahaan", Universitas Negeri Yogyakarta, Vol. 4 No. 2, 2015, h. 2.

${ }^{2}$ Robert Anthony dan Vijay Govindarajan, Manajemen Control System, (Jakarta: Salemba Empat, 2009), h. 63.

${ }^{3}$ Aldina Dewi Endarwati "Analisis Pengungkapan Corporate Social Responsibility Terhadap Kinerja Keuangan Perusahaan Pada Perusahaan Otomotif Yang Terdaftar Di Bursa Efek Indonesia" (Skripsi Fakultas Ekonomi Universitas Pembangunan Nasional Veteran, Jawa Timur, 2013), h. 1.
} 
eksternal tersebut mengganggu bahkan dapat menghentikan operasi perusahaan. Citra perusahaan akan semakin baik di mata masyarakat apabila dapat menunjukkan tanggung jawab dan kepeduliannya terhadap lingkungan eksternal. Adanya fenomena diatas menyebabkan dunia bisnis mengalami pergeseran orientasi, yaitu dari shareholders ke stakeholders. Tanggung jawab sosial perusahaan diperlukan untuk menjaga keharmonisan hubungan antara perusahaan dengan lingkungan sekitarnya.

Konsep ini memuat pengertian bahwa bisnis tidak hanya sekedar mencari keuntungan (profit) melainkan juga kesejahteraan orang (people) dan menjamin keberlangsungan hidup. Konsep CSR berkaitan erat dengan keberlangsungan atau suistainbility perusahaan. Konsep CSR mengharuskan perusahaan untuk mengambil keputusan dan melaksanakan aktivitas perusahaan tidak hanya mengacu pada profitabilitas saja melainkan juga berdasarkan konsekuensi sosial dan lingkungan untuk saat ini maupun masa yang akan datang. ${ }^{4}$ CSR sebagai konsep akuntansi yang baru merupakan transparasi pengungkapan sosial atas aktivitas sosial yang dilakukan perusahaan tidak hanya berfokus pada single bottom line yaitu tanggung jawab perusahaan yang hanya berfokus pada kondisi keuangan saja, namun harus berfokus pada aspek ekonomi, sosial dan lingkungan.

Dalam UU No. 40 Tahun 2007 tentang Perseroan Terbatas, pada bab IV, bagian kedua, pasal 66 (2), poin c yang mengatur tentang laporan tahunan, disebutkan bahwa direksi harus menyampaikan laporan tahunan yang sekurang-kurangnya memuat laporan pelaksanaan tanggung jawab sosial dan lingkungan. ${ }^{5}$

Dalam perspektif Islam CSR merupakan konsekuensi inhern dari ajaran Islam itu sendiri. Tujuan dari syariat Islam (Maqashid al syariah) adalah maslahah sehingga bisnis adalah upaya untuk menciptakan maslahah bukan sekedar mencari keuntungan. Tanggung jawab sosial dalam Islam bukanlah hal yang asing, ia sudah ada dan diamalkan sejak 14 abad yang silam. Dalam al-Qur'an pembahasan mengenai tanggung jawab sosial sangat sering disebutkan. Al-Qur'an selalu mengaitkan antara

${ }^{4}$ Ibnu Dipraja "Pengaruh Corporate Social Responsibility Terhadap Kinerja Keuangan" (Laporan Penelitian Fakultas Ekonomika dan Bisnis Universitas Dian Nuswantara, Semarang, 2012), h. 2.

5 Budi Cahyono "Pengaruh Corporate Social Responsibility Terhadap Kinerja Perusahaan Dengan Kepemilikian Asing Sebagai Variabel Moderating" (Skripsi Fakultas Ekonomi Universitas Diponegoro, Semarang, 2011), h. 2. 
kesuksesan bisnis dan pertumbuhan ekonomi sangat dipengaruhi oleh moral pelaku bisnis dalam menjalankan kegiatan ekonomi. Adapun terhadap lingkungan, al-Qur'an memberikan perhatian yang amat serius untuk selalu menjamin keharmonisan dan kelestarian lingkungan hidup. Pada sisi kedermawanan dan kebajikan, Islam sangat menganjurkan kedermawanan sosial kepada orang-orang yang membutuhkan dan kurang mampu dalam berusaha melalui sadaqah dan pinjaman kebajikan (qard hasan).

Pelaksanaan CSR yang optimal akan berimpact kepada baiknya hubungan antara perusahaan dan masyarakat, hubungan yang terjalin antara masyarakat dan perusahaan akan membuat kehidupan masyarakat akan lebih baik. dalam Islam, pada prinsipnya bisnis haruslah tidak melanggar norma utamanya.

Setiap entitas bisnis yang memegang prinsip Islam haruslah berperan tidak hanya untuk orientasi keuntungan semata namun, juga harus ditujukan untuk mencapai ridho Allah Ta'ala sehingga pertanggungjawaban operasional perusahaan tidak hanya sekedar bisnis saja tetapi juga kepada Allah, masyarakat dan lingkungan. Tanggung jawab manusia dalam hal ini sebagai pelaku bisnis minimal ada dua hal, yaitu sebagai pengelola sumber daya yang ada untuk kepentingan masyarakat, dan tanggung jawab dengan mengorbankan kepentingan pribadinya (sukarela) demi mencapai tujuan ekonomi yaitu falah (terwujudnya tingkat pertumbuhan ekonomi jangka panjang dan memaksimalkan kesejahteraan manusia).

Untuk mengukur keberhasilan sebuah entitas bisnis dalam melaksanakan prioritas kebutuhan dalam pencapaian falah maka Islam telah memberikan panduan dengan adanya prinsip ekonomi syariah.

Penelitian terkait dengan prinsip ekonomi syariah terhadap pengungkapan CSR memang belum banyak dilakukan di Indonesia, namun sudah ada beberapa peneliti yang pernah melakukannya. Seperti penelitian yang dilakukan oleh Lila Kondi Dabutar tahun 2017, dalam penelitian tersebut peneliti berusaha untuk mengungkapkan keberadaan nilai-nilai muqashid al-syariah dalam laporan tahunan perbankan syariah serta untuk membandingkan kandungan nilai-nilai maqashid al-syariah yang tercantum pada laporan tahunan bank syariah di Indonesia dengan menggunakan indikator CSR sebagai tolak ukur. 
Penelitian yang akan penulis lakukan didasarkan pada penelitian yang dilakukan oleh Lila Kondi Dabutar, jika penelitian yang dilakukan oleh Lila berusaha untuk mengungkap nilai-nilai maqashid al-syariah dalam laporan tahunan perbankan dan membandingkan antara bank satu dengan bank lain maka penelitian yang akan peneliti lakukan hendak menakar prinsip ekonomi syariah terhadap pengungkapan CSR yang selanjutnya melihat implementasi prinsip ekonomi syariah terhadap pengungkapan CSR itu sendiri.Berdasarkan latar belakang yang telah diuraikan diatas, dapat diambil rumusan masalah sebagai berikut Apakah yang dimaksud dengan Corporate Social Responsibility (CSR) dan Apakah Pengungkapan Corporate Social Responsibility (CSR) sesuai dengan Prinsip Ekonomi Syariah .

\section{METODE}

\section{Jenis Penelitian}

Jenis penelitian yang digunakan pada penelitian ini adalah penelitian kualitatif, karena data yang disajikan dalam bentuk kata-kata bukan angka. Karena itu deskripsinya membutuhkan penafsiran (interpretasi) untuk mengetahui makna di balik kata.

2. Pendekatan Penelitian

Pendekatan penelitian yang digunakan dalam penelitian ini adalah pendekatan ekonomi Islam. Ekonomi Islam memiliki sifat dasar sebagai ekonomi Rabbani dan Insani. Dikatakan ekonomi Rabbani karena ekonomi Islam sarat dengan tujuan dan nilai-nilai Ilahiyah. Sedangkan ekonomi Insani, karena sistem ekonomi Islam dilaksanakan dan ditujukan untuk kemaslahatan manusia.

Dalam penelitian ini pendekatan ekonomi Islam digunakan untuk menganalisa prinsip-prinsip Islami dalam mengidentifikasi serta mengukur nilai-nilai prinsip ekonomi syariah terhadap pengungkapan Corporate Social Responsibility (CSR).

3. Sumber dan Pengumpulan Data

Pengumpulan data dilakukan untuk memperoleh informasi yang dibutuhkan dalam rangka mencapai tujuan penelitian. Dalam hal ini, jenis data yang digunakan 
pada penelitian ini, yaitu data sekunder yang berupa data laporan tahunan (annual report) perusahaan dan juga melalui website www.idx.co.id. Data penelitian ini meliputi data perusahaan yang berupa laporan tahunan (annual report) perusahaan PT. Semen Tonasa, Tbk.

Pengumpulan data dilakukan untuk memperoleh informasi yang dibutuhkan dalam rangka mencapai tujuan penelitian. Data sekunder ialah data yang diperoleh secara tidak langsung, terdiri dari dokumen-dokumen, surat, dokumen-dokumen resmi dari instansi pemerintah, laporan keuangan dan lain sebagainya yang berupa arsip perusahaan. ${ }^{6}$ Data sekunder sangat bermanfaat untuk menghemat waktu dan biaya karena data telah tersedia.

Adapun metode yang digunakan untuk pengumpulan data dalam penelitian ini adalah:

\section{Observasi}

Observasi adalah pengamatan yang dilakukan oleh seorang peneliti baik secara langsung maupun tidak langsung terhadap suatu objek yang diteliti dengan menggunakan instument yang berupa pedoman penelitian dalam bentuk lembaran pengamatan lainnya. ${ }^{7}$ Observasi adalah alat pengumpulan data yang sistematis, yang artinya kegiatan observasi mulai dari pencatatan dilakukan menurut prosedur dan aturan-aturan tertentu sehingga dapat diulangi kembali oleh peneliti lain. Selain itu hasil observasi harus memberi kemungkinan untuk menafsirkan sesuatu secara ilmiah ${ }^{8}$. Dalam penelitian ini, metode observasi digunakan untuk mengumpulkan dan memperoleh informasi mengenai pengungkapan CSR.

\section{Dokumentasi}

Dokumentasi adalah proses pengumpulan data secara tertulis yang mengandung keterangan dan penjelasan serapemikiran tentang fenomena yang masih akurat dan sesuai dengan masalah penelitian. ${ }^{9}$ Wujud metode dokumentasi dalam penelitian ini yaitu berupa data mengenai perusahaan PT. Semen Tonasa, Tbk.

${ }^{6}$ Nasution, Metode Research; Penelitian IImiah, (Cet, 3; Jakarta: PT Bumi Aksara, 2000), h. 143.

${ }^{7}$ Muhammad, Metode Penelitian Ekonomi Islam: Pendekatan Kuantitatif, Eds. I (Cet. I; Jakarta: Rajawali Pers, 2008), h. 122.

${ }^{8}$ Nasution, Metode Research, h. 107.

${ }^{9}$ Suharsimi Arikunto, Prosedur Penelitian, h. 206. 


\section{Tehnik Analisis Data}

Dalam menganalisis data penulis menggunakan metode analisis isi (content analysis). Neoendroff mendefinisikan analisis isi sebagai suatu analisis mendalam yang dapat menggunakan teknik kuantitatif maupun teknik kualitatif terhadap pesan-pesan menggunakan metode ilmiah dan tidak terbatas pada jenis-jenis variabel yang dapat diukur atau konteks tempat pesan-pesan diciptakan atau disajikan. ${ }^{10}$ Adapun yang diungkapkan Holsti bahwa kajian isi adalah teknik apapun yang digunakan untuk menarik kesimpulan melalui usaha menemukan karakteristik pesan, dan dilakukan secara objektif dan sistematis. ${ }^{11}$ Dari segi penelitian kualitatif tampaknya definisi terakhir lebih mendekati teknik yang diharapkan. Dalam analisis isi kualitatif ada dua pengembangan prosedur yakni pengembangan kategori induktif dan pengembangan kategori deduktif. Namun dalam penelitian ini prosedur analisis isi yang digunakan adalah pengembangan kategori induktif. Adapun prosedur analisis isi dalam pengembangan kategori induktif adalah sebagai berikut;

a. Pertanyaan penelitian. Pertanyaan dalam penelitian ini telah penulis sajikan dalam rumusan masalah.

b. Penentuan definisi kategori (kriteria seleksi) dan level abstraksi untuk kategori induktif. Dalam tahap ini merumuskan suatu kriteria dari definisi yang diturunkan dari latar teoritis dan pertanyaan penelitian. Penulis akan mengategorikan konsep prinsip ekonomi syariah begitupun dengan pengungkapan CSR.

c. Tahap demi tahap perumusan kategori di luar materi, mengenai definisi kategori dan level abstraksi. Subsumsi kategori lama atau perumusan kategori lama.

d. Revisi kategori-kategori setelah $10-50 \%$ dari materi. ${ }^{12}$ Di dalam suatu lingkaran umpan balik kategori-kategori ini direvisi, akhirnya direduksi menjadi kategorikategori pokok dan dicek sehubungan dengan realibitasnya. Dalam hal ini pengecekan realibitas secara formatif.

${ }^{10}$ Emzir, Metode Penelitian Kualitatif: Analisis Data, (Cet. IV; Jakarta: Rajawali Pers, 2014), h. 284.

${ }^{11}$ Lexy Moleong, Metodologi Penelitian Kualitatif, (Cet. XX; Bandung: PT Remaja Rosdakarya, 2004), h. 220.

${ }^{12}$ Dalam referensi lain, menurut Philip Mayring menyebutkan revisi kategori sesudah $10-15 \%$. 
e. Pekerjaan akhir dari keseluruhan dan selanjutnya pengecekan realibitas secara sumatif.

f. Interpretasi hasil. Langkah terakhir dalam analisis data kualitatif menurut Miles dan Huberman adalah penarikan kesimpulan dan verifikasi. ${ }^{13}$ Setelah menganalisis isi dari data yang diperoleh, maka penulis menarik kesimpulan atas penelitian yang dilakukan untuk melihat apakah pengungkapan CSR sesuai dengan prinsip ekonomi syariah.

\section{HASIL DAN PEMBAHASAN}

Konsep Corporate Social Responsibility (CSR) dalam syariah sebagai way of life memberikan panduan bagi umatnya untuk beradaptasi dan berkembang pada eranya. Islam memungkinkan umatnya untuk berinovasi dalam muamalah, namun tidak dalam akidah, ibadah dan akhlaq. Lembaga yang menjalankan bisnisnya berdasarkan syariah pada hakekatnya mendasarkan pada filosofi dasar al-Qur'an dan Sunah. Sehingga hal ini menjadikan dasar bagi pelakunya dalam berinteraksi dengan lingkungan dan sesamanya. Implikasinya ikatan hubungan antara institusi dengan lingkungannya dalam konsep syariah akan lebih kuat daripada dalam konsep konvensional. Hal ini terjadi karena pada sistem syariah didasarkan pada dasar-dasar relijius. Dimana tolak ukur pertanggungjawaban atas segala aktivitasnya adalah untuk mencapai ridha Allah semata. Pada akhirnya hubungan dan tanggungjawab antara manusia dengan Allah ini akan melahirkan kontrak religius yang lebih kuat dan bukan sekedar kontrak sosial.

Konsep CSR dijalankan sesuai dengan firman Allah yang artinya; "bukanlah menghadapkan wajahmu ke arah timur dan barat itu suatu kebajikan, akan tetapi Sesungguhnya kebajikan itu ialah beriman kepada Allah, hari Kemudian, malaikatmalaikat, kitab-kitab, nabi-nabi dan memberikan harta yang dicintainya kepada kerabatnya, anak-anak yatim, orang-orang miskin, musafir (yang memerlukan pertolongan) dan orang-orang yang meminta-minta; dan (memerdekakan) hamba sahaya, mendirikan shalat, dan menunaikan zakat; dan orang-orang yang menepati janjinya apabila ia berjanji, dan orang-orang yang sabar dalam kesempitan, penderitaan

${ }^{13}$ Sugiyono, Metode Penelitian Kuantitatif, h. 252. 
dan dalam peperangan. mereka Itulah orang-orang yang benar (imannya); dan mereka Itulah orang-orang yang bertakwa". (QS. Al Baqarah: 177). ${ }^{14}$

Makna dalam ayat tersebut bila dikaitkan dengan CSR adalah bahwa praktik bisnis yang memiliki tanggung jawab etis secara islami. Perusahaaan diharuskan memasukan normanorma agama islam yang ditandai dengan adanya komitmen ketulusan dalam menjaga kontrak sosial di dalam operasinya. Pada akhirnya, praktik bisnis dalam kerangka CSR Islami mencakup serangkaian kegiatan bisnis dalam bentuknya. Meskipun tidak dibatasi jumlah kepemilikan barang, jasa serta profitnya, namun cara-cara untuk memperoleh dan pendayagunaannya dibatasi oleh aturan halal dan haram oleh syariah.

CSR dalam perspektif Islam menurut AAOIFI yaitu segala kegiatan yang dilakukan institusi financial Islam untuk memenuhi kepentingan religius, ekonomi, hukum, etika, dan discretionary responsibilities sebagai lembaga fianansial intermediari baik bagi individu maupun institusi. ${ }^{15}$

Menurut Syariah, CSR yang dilakukan harus bertujuan untuk menciptakan kebajikan yang dilakukan bukan melalui aktivitas-aktivitas yang mengandung unsur riba, melainkan dengan praktik yang diperintahkan Allah berupa zakat, infak, sedekah, dan wakaf. CSR juga harus mengedepankan nilai kedermawanan dan ketulusan hati . Perbuatan ini lebih Allah cintai dari ibadah-ibadah mahdhah. Rasulullah SAW bersabda, "Memenuhi keperluan seorang mukmin lebih Allah cintai dari pada melakukan dua puluh kali haji dan pada setiap hajinya menginfakan ratusan ribu dirham dan dinar". Dalam hadis lain, Rasulullah SAW juga bersabda, "Jika seorang muslim berjalan memenuhi keperluan sesama muslim, itu lebih baik baginya daripada melakukan tujuh puluh kali thawaf di Baitullah." Selain itu, pelaksanaan CSR dalam Islam juga merupakan salah satu upaya mereduksi permasalahan-permasalahan social yang terjadi di masyarakat dengan mendorong produktivitas masyarakat dan menjaga keseimbangan distribusi kekayaan di masyarakat. Islam mewajibkan sirkulasi kekayaan terjadi pada semua anggota

${ }^{14}$ Naning Fatmawatie, "Pengungkapan CSR dalam Akuntansi Sosial Ekonomi di Tinjau dari Syariah", Jurnal, vol. 3, No.2, Desember 2015, h. 233.

${ }^{15}$ Naning Fatmawatie, "Pengungkapan CSR dalam Akuntansi, h. 233. 
masyarakat dan mencegah terjadinya sirkulasi kekayaan hanya pada segelintir orang. Allah SWT berfirman: “....supaya harta itu jangan beredar di antara orang-orang kaya saja di antara kamu." (QS. Al-Hasyr: 7)

Tanggungjawab etis praktik CSR dalam pelaporan untuk pengungkapan aktivitas-aktivitas CSR kepada masyarakat penting sekali dilakukan. Hal ini sesuai dengan prinsip-prinsip mendasar yang membentuk filosofi kebajikan lingkungan yang dilakukan secara holistik oleh Nabi Muhamad SAW adalah keyakinan akan adanya saling ketergantungan di antara makhluk ciptaan Allah. Karena Allah SWT menciptakan alam semesta ini secara terukur, baik kuantitatif maupun kualitatif . Hal ini sesuai dengan (QS. Al-Qamar: 49) dan dalam kondisi yang seimbang. Hal ini sesuai dengan QS. Al-Hadid: 7. Pada ayat ini tampak nyata terdapat sifat saling ketergantungan antara makhluk hidup adalah sebuah fitrah dari Allah SWT. Berdasarkan prinsip ini maka konsekuensinya adalah jika manusia merusak atau mengabaikan salah satu bagian dari ciptaan Allah SWT, maka alam secara keseluruhan akan mengalami penderitaan yang pada akhirnya juga akan merugikan manusia. Hal itu sesuai dengan firman Allah SWT yang artinya: "Telah nampak kerusakan di darat dan di laut disebabkan karena perbuatan tangan manusia, supaya Allah merasakan kepada mereka sebahagian dari (akibat) perbuatan mereka, agar mereka kembali (ke jalan yang benar)". (QS. Ar-Rum: 41).

Dalam konteks Syariah, masyarakat mempunyai hak untuk mengetahui berbagai informasi mengenai aktivitas organisasi. Hal ini dilakukan untuk melihat apakah perusahaan tetap melakukan kegiatannya sesuai syariah dan mencapai tujuan yang telah ditetapkan. Jadi, dari indikator-indikator pengungkapan CSR yang telah peneliti kaji mulai dari dimensi lingkungan, sosial, ekonomi, hak asasi manusia, tenaga kerja, dan produk relevan dengan prinsip ekonomi syariah.

\section{KESIMPULAN DAN SARAN}

\section{Kesimpulan}

Pengungkapan melalui laporan tanggung jawab sosial yang merupakan output dari akuntansi sosial ekonomi akan membantu pemakai laporan keuangan untuk 
menganalisis sejauh mana perhatian dan tanggung jawab sosial perusahaan dalam menjalankan bisnis. Pengungkapan tanggung jawab sosial meliputi aspek ekonomi, aspek sosial, aspek lingkungan, aspek tenaga kerja, aspek hak asasi manusia, dan aspek produk yang terjadi di perusahaan. Tanggung jawab sosail dalam praktik CSR untuk pengungkapan aktivitas-aktivitas CSR kepada masyarakat penting sekali dilakukan. Hal ini sesuai dengan prinsip-prinsip mendasar yang membentuk filosofi kebajikan lingkungan yang dilakukan secara holistik oleh Nabi Muhamad SAW. yaitu keyakinan akan adanya saling ketergantungan di antara makhluk ciptaan Allah. Islam mewajibkan sirkulasi kekayaan terjadi pada semua anggota masyarakat dan mencegah terjadinya sirkulasi kekayaan hanya pada segelintir orang. Allah SWT berfirman: “....supaya harta itu jangan beredar di antara orang-orang kaya saja di antara kamu." (QS. Al-Hasyr: 7)

\section{Saran}

Berdasarkan kesimpulan diatas, maka penulis memberikan saran kepada perusahaan-perusahaan agar menerapkan corporate social responsibility dalam kegiatan perusahaannya karena dapat mendatangkan manfaat bagi perusahaan dan dalam tinjauan ekonomi Islam apabila dana CSR digunakan dengan baik maka akan mendatangkan manfaat yang besar bagi perusahaan.

\section{DAFTAR PUSTAKA}

Abdad, M. Zaidi. Lembaga Perekonomian Ummat di Dunia Islam. Bandung: Angkasa, 2013.

Aisah, Murni dan Siti. "Pengaruh Luas Pengungkapan Sukarela Dan Asimetri Informasi terhadap cost of capital pada perusahaan publik di indonesia". Jurnal Riset Akuntansi di Indonesia, 2004.

Al-Arif, M. Nur Rianto. Dasar-Dasar Ekonomi Islam. Solo: PT Era Adicitra Intermedia, 2011.

Ali, Zainudin. Hukum Ekonomi Syariah. Jakarta: Sinar Grafika, 2008.

Alma, Buchari dan Donni Juni Priansa. Manajemen Bisnis Syariah, Bandung: Alfabeta, 2009. 
Alma, Buchari dan Donni Juni Priansa. Manajemen Bisnis Syariah. Bandung: Alfabeta, 2013.

Andriyanto, Widdie dan Mega Metalia. "Perbandingan Tingkat Kelengkapan Mandatory Disclosure dan Voluntary Disclosure Informasi Akuntansi Antara Industri HighProfile dan Low-Profile". Jurnal Akuntansi dan Investasi, Vol. 12, No. I, Januari 2011.

Anthony, Robert dan Vijay Govindarajan. Manajemen Control System, Jakarta: Salemba Empat, 2009.

Aryawan, Made Dkk. "Pengaruh Faktor CSR (Aspek Sosial, Ekonomi dan Lingkungan) terhadap Citra Perusahaan", Jurnal Manajemen. Vol. 6, No. 2, 2017.

As-Sa'di, Syeik Abdurrahman bin Nashir. Taisir al-Karim ar-Rahman Fi Tafsir Kalam alMannan, Terj. Muhammad Ikbal Dkk, Tafsir Al-Qur’an, Jakarta: Darul Haq, 2016.

Astuti, M.B. Hendrie dan Dwi Retni. "Persepsi Stakeholders Terhadap Pelaksanaan Corporate Social Responsibility Kasus Pada Bank Syariah DIY", Sinergi: Kajian Bisnis dan Manajemen, Vol. 10 No. 1, Januari 2008.

B. Robinson, John A. Pearce II dan Richard. Strategic Management: Formulation, Implementation and Control, Terj. Nia Pramita Sari, Manajemen Strategi: Formulasi, Implementasi dan Pengendalian. Jakarta: Salemba Empat, 2013.

Cahyono, Budi. "Pengaruh Corporate Social Responsibility Terhadap Kinerja Perusahaan Dengan Kepemilikian Asing Sebagai Variabel Moderating" Skripsi Fakultas Ekonomi Universitas Diponegoro, Semarang, 2011.

Chaudhry, Muhammad Sharif. Sistem Ekonomo Islam. Jakarta: Kencana Prenada Media Group, 2012.

Dabutar, Lila Kondi. "Eksplorasi nilai-nilai maqashid al-syariah dalam laporan tahunan perbankan syariah di Indonesia studi Bank Mumalat Indonesia, Bank Syariah Mandiri, Bank Negara Indonesia Syariah". Skripsi, Semarang, Fakultas Ekonomika dan Bisnis, Universitas Deponegoro, 2017.

Darwin, Ali. Penerapan Sustainability Reporting di Indonesia. Konvensi Nasional Akntansi V, Program Profesi Lanjutan. Yogyakarta, 13-15 Desember 2004.

Dewi,Valeria Adelwais Sartika. "Analisis Pengungkapan Corporate Social Responsibility (CSR) Berdasarkan Karakteristik Perusahaan", Skripsi, Salatiga, Fakultas Ekonomika dan Bisnis, Universitas Kristen Satya Wacana, 2013.

Dipraja, Ibnu. "Pengaruh Corporate Social Responsibility Terhadap Kinerja Keuangan" Laporan Penelitian Fakultas Ekonomika dan Bisnis Universitas Dian Nuswantara. Semarang, 2012.

Emzir. Metode Penelitian Kualitatif: Analisis Data. Jakarta: Rajawali Pers, 2014.

Endarwati, Aldina Dewi. "Analisis Pengungkapan Corporate Social Responsibility Terhadap Kinerja Keuangan Perusahaan Pada Perusahaan Otomotif Yang 
Terdaftar Di Bursa Efek Indonesia" Skripsi Fakultas Ekonomi Universitas Pembangunan Nasional Veteran, Jawa Timur, 2013.

Eriandani, Rizky. "Pengaruh Pengungkapan Corporate Social Responsibility Terhadap Future Institutional Ownership". Jurnal, Vol. XVII, No. April 2014.

Fatmawatie, Naning. "Pengungkapan CSR dalam Akuntansi Sosial Ekonomi di Tinjau dari Syariah”, Jurnal, vol. 3, No.2, Desember 2015.

Gumelar, Farid. "Keadilan Ekonomi dalam Perspektif Ekonomi Syariah". Artikel, 2011.

Hadi, Nor. Corporate Social Responsibility. Yogyakarta: Graha IImu, 2011.

Hastuti, Nindri. "Pengaruh Tanggung Jawab Sosial Perusahaan (Corporate Social Responsibility) Tehadap Nilai Perusahaan Study Empiris pada Perusahaan Manufaktur yang terdaftar di BEI periode 2013 dan 2014". Skripsi, Fakultas Ekonomi Universitas Negeri Yogyakarta, 2016.

Juwita, Ratna. "Analisis Pelaksanaan Tanggung Jawab Sosial Perusahaan (CSR) PT Palm Lampung Persada di Desa Bumi Agung Kabupaten Way Kanan". Skripsi, Bandar Lampung, Fakultas Hukum, universitas Lampung, 2016.

Maiyarni, Reka Dkk. "Pengaruh Profitabilitas, Ukuran Perusahaan, Likuiditas, dan Leverage terhadap Pengungkapan CSR pada Perusahaan LQ-45 pada Perusahaan yang terdaftar di BEl Periode 2009-2012'. Jurnal Akuntansi, Vol. 6 No. 1, Februari 2014.

Mardani, Hukum Ekonomi Di Indonesia. Bandung: PT Refika Aditama, 2011. 